\title{
GELIAT SYIAH DAN PERUBAHAN PAHAM SERTA PERILAKU KEAGAMAAN MAHASISWA MUSLIM DI KOTA MAKASSAR \\ The Stretching and Shiite and Changes of Religion Understanding and Behavior among Moslem Student in Makassar City
}

\section{Oleh: Sahara*}

* Calon Peneliti pada Balai Penelitian dan Pengembangan Agama Makassar Kantor: Jalan AP. Pettarani No. 72 Makassar E-mail: barackfi1safat(@,vahoo.co.id

\begin{abstract}
Abstrak
Selama dua dasawarsa terakhir, di kota Makassar terjadi fenomena perkembangan Syiah yang cukup massif, dan yang menarik dari fenomena tersebut adalah sebagian besar yang menjadi aktor dalam fenomena tersebut adalah kalangan mahasiswa muslim. Dengan tujuan untuk mendeskripsikan perkembangan, proses kaderisasi, dan perubahan paham dan sikap keagamaan mahasiswa muslim yang menjadi penganut Syiah di Kota Makassar, maka dilakukan penelitian ini dengan menggunakan metode penelitian kualitatif dan pendekatan deskriptif-analisis dengan menggali informasi dari kalangan mahasiswa yang menjadi fokus penelitian ini. Syiah cukup familiar dikenal oleh mahasiswa Makassar meski mereka memiliki car a pandang yang berbeda dalam menilai dan menyikapi Syiah. Perkembangan Syiah di kota Makassar ditunjang oleh keberadaan IJABI sebagai ormas dan didukung oleh 9 yayasan Syiah dan berbagai kelompok studi yang ada di kampus-kampus. Pendekatan yang digunakan dalam melakukan penetrasi Syiah adalah pendekatan intelektual dan melakukan transformasi semangat revolusi Islam Iran yang cukup memantik minat kalangan mahasiswa, khususnya kalangan aktivis. Perkembangan Syiah di kalangan mahasiswa muslim tersebut menimbulkan pengaruh perubahan pada paham dan prilaku keagamaan yang mengikuti pada pola pemahaman dan prilaku keagamaan berdasarkan ajaran Syiah.
\end{abstract}

Kata Kunci: Syiah, Mahasiswa, Paham dan Prilaku Keagamaan

\section{Abstract}

Over the last two decades in Makassar city, there have been a phenomenon of massive progress Syiah (Shiite), and the interesting part of the phenomenon is largely the actors in the phenomenon are among Muslim students. With the aim to describe the development, the process of regeneration, and changes in religious beliefs and attitudes of students who become followers of Shiite Muslims in Makassar, then it is carried out this research using qualitative research methods and descriptive approaches analysis by exploring the information from the student who becomes the focus of this study. Shiite is quite familiar known by students in Makassar even though they have a different perspective in assessing and addressing the Shiite. Developments in the Shiite in of Makassar city supported by the existence IJABI as mass organizations and supported by 9 Shiite foundations and various study groups that exist on college campuses. The approach used in conducting penetration intellectual approach and encourage the spirit of Iran Islamic revolution that quite sparked the interest among students, especially to the activists. The progress of Shiite among Muslim student has been influenced the changes in religious beliefs and behaviors that follow the pattern of religious understanding and behavior based on the teachings of Shiite.

Key Words: Shiite, students, religious beliefs and behaviors

\section{PENDAHULUAN}

$\mathrm{P}$ erjalanan sejarah Nusantara ditandai dengan berbagai unsur kebudayaan yang berinteraksi dengan paham keagamaan yang masuk. Salah satu yang menonjol dan sering menimbulkan banyak perdebatan adalah tradisi masyarakat di Nusantara dalam sejarah Islam awal di Nusantara. Sehingga polemik sejarah itu tak kunjung usai antara fakta dan mitos. Dalam konteks sejarah perkembangan gerakan Ahlulbayt atau lebih spesifik paham keagamaan Syiah di Nusantara, kita mendengar dan membaca ada kesan yang tidak tuntas. Tidak sedikit yang mendukung analisis bahvva perkembangan Islam di Indonesia pada awalnya adalah dipelopori oleh Islam Syiah, tetapi terdapat juga pandangan yang melihat adanya hipotesis tersebut oleh karena merunut pada kesamaan tradisi sajatanpa memiliki signifikansi 
kerangka teologi dan ideologi politik Syiah. yang paling sering dikutip adalah tradisi an hari Asyura, peringatan syahidnya Imam

Di Padang Karbala pada tanggal 10 Muharram <i H. peringatan ini di Aceh dikenal sebagai bulan in Usen", di Sumatera Barat dikenal sebagai - -- rabuik", dan di Jawa sebagai bulan "Suro'V :-:-n. sejarah kebudayaan Islam di Indonesia

-.: tradisi seperti dalam tradisi Ahlulbayt dan :si kebudayaan mereka misalnya tidak lepas pengkhidmatan kepada Ahlulbayt Nabi. _n apakah itu dibentuk dan dikembangkan oleh

$\backslash$ ah atau tidak menjadi masalah. Kita tidak mseadm.

tngkan klaim tetapi nilai sebuah kebudayaan

\section{$1 \quad y$}

- Makassar dalam dua dasawarsa terakhir, nya di kalangan aktivis muda, terjadi sebuah

a menarik. Ghirah keislaman kalangan muda

- ^riatar belakang aktivis kampus mengalami

"gkatan yang cukup signifikan. Gejala ini

- Nibatkan tumbuhnya berbagai halaqah-

-: dan kelompok studi keislaman di berbagai

" " • dan penjuru kota Makassar. Ghirah ini berpadu emangat mengkaji, mengamalkan, memper-

- an. dan memperjuangkan Islam sebagai sebuah nilai dan ideologi. Berbagai kelompok kajian

- an pun muncul, yang mengakibatkan munculnya . Idian dialektika pemikiran dan gerakan Islam, terkadang sering mengalami pergesekan dan

" -*an satu sama lain.

${ }^{D}$ emikiran dan ideologi Islam yang berafiliasi

- niazhab Ahlulbayt (Syiah), menjadi salah satu

- dari sekian banyak alternatif corak pemikiran :eologi keislaman yang ada. Berbeda dengan yang lain, mereka yang tertarik dan ber. dengan mazhab Ahlulbayt merupakan kalangan - - ;• ang di samping memiliki ghirah keislaman yang cinggi, juga memiliki kecenderungan untuk

i Islam dengan pendek-atan intelektual dan -at yang revolusioner. Mazhab Ahlulbayt pun - aii pilihan, khususnya ketika gelombang pemikiran - sohisi Islam Iran merarhbah masuk melalui pemikir-

" $r$ dan ideolog revolusi Islam Iran, seperti

ah Khomeini, Murtadha Muthahhari, Ali $>$ ar-.ati, dan pemikir Syiah lainnya.
Tak bisa dipungkiri, paling tidak dalam dua dasawarsa terakhir, terjadi "ledakan" sosial, khususnya di kalangan aktivis muda Makassar yang memiliki kecenderungan pada intelektualisme dan semangat revolusi untuk berbondong-bondong melakukan pengkajian terhadap pemikiran Islam dari kalangan mazhab Ahlulbayt. Dengan itu, terjadi massifikasi persebaran pengikut mazhab Ahlulbayt di Kota Makassar hingga merembet ke daerah-daerah lain di sekitarnya. Fenomena ini menjadi sangat menarik menjadi objek penelitian guna mengurai fakta tentang perkembangan Syiah di kalangan mahasiswa muslim di Kota Makassar serta perubahan sosial keagamaan yg ditimbulkannya.

Berdasarkan latar belakang di atas, maka penelitian ini fokus pada tiga permasalahan, yaitu: Pertama. Bagaimana pandangan mahasiswa Islam di Makassar terhadap Syiah? Kedua. Bagaimana proses kaderisasi Syiah dan penanaman paham dan perilaku keagamaan pada Mahasiswa Islam di Kota Makaasar? Ketiga. Bagaimana dinamika keberagamaan mahasiswa Islam yang menjadi penganut Syiah di Makassar? Adapun tujuan dari penelitian ini adalah mendeskripsikan perkembangan, proses kaderisasi, dan perubahan paham dan sikap keagamaan mahasiswa muslim yang menjadi penganut Syiah di Kota Makassar.

Metode penelitian yang digunakan dalam penelitian ini adalah penelitian kualitatif yang dilakukan di Kota Makassar. Data diperoleh dengan menggunakan wawancara mendalam, observasi, dan dokumentasi dari data-data yang didapatkan di lapangan. Fokus utama penelitian ini adalah maha-siswa muslim yang telah mengalami perpindahan anutan mazhab keislaman yang kemudian menjadi pengikut Syiah Imamiyah. Selain itu informan lain juga diambil dari mahasiswa muslim yang tidak menganut paham Syiah terkait dengan pandangan mereka terhadap Syiah, serta dari tokoh-tokoh yang intensif dan aktif melakukan kaderisasi dan penyebaran paham Syiah terkait dengan pola kaderisasi dan metode dakwah yang mereka lakukan. Data yang dikumpulkan dianalisis dengan teknik analisisdeskriptif, yaitu seluruh data yang diperoleh baik

ik pembahasan yang detail lihat artikel Azyumardi Azra. 1995. Syiah di Indonesia; Antara Mitos dan Realitas, Jurnal Ulumul Qur'an VI, Tahun 1995.

Safvvan. 2010. Ijabi Sebagai Gerakan Sosial Keagamaan, dalam http://ressay.wordpress.com/2007/01/05/ikatan-jamaah-Ahlulbayt^-ijabi-sebagai-gerakan-sosial-keagamaan/ diakses tanggal 22 Oktober 2010. 
melalui wawancara, observasi, maupun dokumentasi dideskripsikan berdasarkan rumusan masalah penelitian.

\section{Tinjauan Pustaka}

\section{Mengenal Syiah dan Perkembangannya di Indonesia}

Syiah adalah mazhab dalam Islam yang berbeda dengan kelompok Islam mainstream (arus utama) yang dikenal sebagai kelompok Sunni. Istilah Syi'ah berasal dari kata bahasa Arab Syi'ah. Bentuk tunggal dari kata ini adalah $\mathrm{yj}^{*} \mathrm{r}^{\wedge}$ Syi'i. "Syi'ah" adalah bentuk pendek dari kalimat bersejarah Syi'ah 'Ali ${ }^{2 i} \boldsymbol{i}^{\wedge} \boldsymbol{J}^{\prime \prime}$ artinya "pengikut Ali". Syi'ah menurut etimologi bahasa Arab bermakna: pembela dan pengikut seseorang. Selain itujuga bermakna: Setiap kaum yang berkumpul di atas suatu perkara. Adapun menurut terminologi syariat, Syiah bermakna: Mereka yang menyatakan bahwa Ali bin Abi Thalib sangat utama di antara para sahabat dan lebih berhak untuk memegang tampuk kepemimpinan kaum muslimin, demikian pula anak cucu sepeninggal beliau. ${ }^{3}$ Dalam perkembangannya mazhab Syiah kemudian terpecah menjadi beberapa sekte, yaitu Ismailiyah, Zaidiyah, dan yang terbesar adalah Imamiyah.

Dalam populasi umat Islam di dunia, penganut Syiah diperkirakan antara 10-20\% yang tersebar di berbagai kawasan dunia Islam. Syiah menjadi mayoritas di Iran, Irak, Azerbaijan, dan Bahrain, serta memiliki populasi yang cukup signifikan di Libanon, Syria, Pakistan, India, Bangladesh, Kuwait, Arab Saudi, dan Mesir. Perkembangan penyebaran keyakinan Syiah -dalam hal ini Imamiyah- semakin menemukan momentumnya pasca Revolusi Islam Iran yang terjadi pada tahun 1979. Pasca peristiwa tersebut informasi mengenai Syiah menyebar secara massif, bahkan hingga ke Indonesia.

Di Indonesia, perkembangan gerakan Syiah tidak bisa dilepaskan dari pengaruh Revolusi Islam Iran 1979 yangdipimpin oleh Imam Khomeini. Pengaruh revolusi ini begitu kuat terutama dengan publikasi-publikasi tulisan Ali Syari'ati, Murtadha Muthahhari dan Imam Khomeini sendiri ke dalam bahasa Indonesia yang mendapat respon besar dari pembaca Indonesia, terbukti dari ramainya perbincangan mengenai revolusi dan dasar pemikiran Imam Khomeini mulai paruh tahun 1980. Salah satu tokoh intelektual di Indonesia yang kemudian banyak menjadi referensi dalam perbincangan mengenai Iran dan Syiah oleh publik adalah Dr. Jalaluddin Rakhmat, M.Sc. Dia banyak menulis dan memberi tanggapan mengenai pemikiran Syiah dan juga menjadi pembicara dalam berbagai seminar di Indonesia. Oleh karena itu, peran besar Jalaluddin Rakhmat tidak dapat dilepaskan dalam perkembangan Ahlulbayt di Indonesia. Penerbitan yang bertema sekitar mazhab Ahlulbayt ini juga sangat intens, awalnya oleh penerbit Mizan, terus berkembang dan didukung oleh penerbit lainnya, misalnya, Pustaka Hidayah dan Lentera. Penerbit Mizan sendiri misalnya menerbitkan buku Dialog Sunna Syiah yang dicetak hingga beberapa kali. Penerbitan buku-buku bertema Syiah (berbahasa Indonesia) hingga kini terus berlangsung. Pengiriman pelajar ke Hawzah Ilmiyyah (semacam pondok pesantren) Qum, Iran,juga terlaksana dan hingga kini pengiriman pelajar terus berlangsung. Demikian halnya dengan kembalinya beberapa pelajar yang kemudian mengajarksn pemikiran Syiah di Indonesia, mereka berpartisipasi melalui kelompok pengajian dan yayasan yang dibentuk oleh para pencinta Ahlulbayt karena didorong oleh kepentingan perkembanganjamaah dan kebutuhan untuk melakukan sosialisasi pemikiran Ahlulbayt secara terorganisasi.'

1 Juli 2000 bertempat di gedung Merdeka Bandung, dideklarasikan organisasi yang menghimpun pencinta Ahlulbayt di Indonesia yang bernama Ikatan Jamaah Ahlulbayt Indonesia (IJABI). Pendirian dan pengembangan IJABI dipelopori oleh para pencinta Ahlulbayt dari kalangan Syiah Imamiyah dan dimotori oleh Dr. Jalaluddin Rakhmat, M. Sc yang kemudian berposisi sebagai Ketua Dewan Syuro. Hingga kini IJABI telah melebarkan sayapnya di hampir semua provinsi yang ada di Indonesia.

Selain IJABI, perkembangan Syiah di Indonesia juga banyak dilakukan oleh yayasan-yayasan dan lembaga pendidikan yang tersebar di seluruh Indonesia. Hingga kini di seluruh wilayah provinsi di Indonesia tetlh berdiri yayasan-yayasan. Tidak kurang dari 100-an yayasan Syiah di Indonesia yang intensif

Muhammad Tijani, 2007. al-Syiah hum AM Sunnah, Diterjemahkan dengan Judul Syiah Sebenar-benarnya Ahlussunnah: Study KritisInformatif antara Klaim dan Fakta. Jakarta: el-Faraj, h. 5.

Dan segi akidah, Syiah -dalam hal ini Syiah Imamiyah-meyakini lima rukun iman yang mereka sebut dengan istilah ushul al-din atau ushul khamsah, yaitu Tauhid, Keadilan Ilahi, Kenabian, Imamah, dan hari kebangkitan, Lihat Nasir Makarim Syirazi, 2002 . Inilah Aqidah Syiah, (Jakarta: al-Huda)

AM. Shafwan, loc. cit 
- - _kan pengkajian dan penyebaran mazhab Syiah. :... ada beberapa lembaga pendidikan yangjuga

-" _; motor penggerak berkembangnya paham Syiah ":: r esia. di antaranya SMP-SMU Plus Muthahhari ng. Pesantren YAPI Bangil. Pesantren al-Hadi -an. STAI Madina Ilmi Jakarta. ICAS Jakarta ". - erapa lembaga pendidikan lainnya.

\section{r»ri Paham dan Perilaku Keagamaan}

-oeragamaan seseorang sangat berkaitan erat - - r-erbagai dimensi kehidupannya. Agamaadalah

-" mbol, sistem keyakinan, sistem nilai, dan sistem yang terlembagakan, yang episentrumnya " 'os pada persoalan-persoalan yang dihayati yang paling maknawi (ultimate meaning).

-" .in demikian agama menyentuh sisi yang paling

:a" berpengaruhsecarakomprehensifdalamdiri

- :".:dupan setiap manusia. ${ }^{6}$

aurut Glock dan Stark terdapat lima macam i'si keberagamaan, yang terkait dengan paham $\boldsymbol{\&} \boldsymbol{m}$ prilaku keagamaan, yaitu: Pertama, dimensi

- - "an (ideologis). Dimensi ini sarat dengan irgaan-penghargaan di mana orang religus

$"$ p a d a pandangan teologis tertentu dan kebenaran-kebenaran tersebut sebagai

$\sim i$ ^etiap agama mempertahankan seperangkat - percayaan di manapengikutnya diharapkan untuk -aaiL Kedua. Dimensi peribadatan atau praktek

- - ritaulistik). Aspek ini meliputi prilaku (atti^emujaan atau kultus, ketaatan, dan hal-hal akukan orang untuk mengekspresikan en keagamaannya pada ranah praksis k Keiiga. Dimensi penghayatan (ekspeDimensi ini memuat fakta bahwa semua ' - --rat dengan ekspektasi-ekspektasi tertentu.

:; Dimensi pengetahuan agama(intelektual).

" - ini mengacu pada harapan bahwa pemeluk - paling tidak memiliki seperangkat pengeiiengenai dasar-dasar keyakinan, ritus-ritus, :radisi, dan kitab suci. Kelima. Dimensi alan agama (konsekuensial). Konsekuensi : en agama mengacu pada identifikasi atas

- isi-implikasi dari keyakinan atau kredo agama, pengetahuan, dan keyakinan seseorang agama yang dianutnya. Dan konsekuensi ,-an merupakan bagian dan implikasi dari 4»:initmen keagamaan.?
Agama dalam kehidupan individu berfungsj sebagai suatu sistem nilai yang senantiasa memuat norma-norma tertentu. Secara umum norma-norma tersebut menjadi kerangka acuan dalam bersikap dan bertingkah laku agar sejalan dengan keyakinan agama yang dianutnya. Sebagai sistem nilai, agama memiliki arti yang khusus dalam kehidupan individu serta dipertahankan sebagai bentuk yang memiliki ciri khas. Dilihat dari fungsi dan perannya, agama memberikan pengaruh terhadap individu dalam bentuk sistem nilai, motivasi, maupun pedoman hidup.

\section{Temuan dan Pembahasan}

\section{Kondisi Kemahasiswaan di Kota Makassar}

Sebagai ibukota provinsi dan kota metropolitan, Kota Makassar tentu saja menjadi pusat pendidikan, bukan hanya untuk provinsi Sulawesi Selatan tapijuga daerah-daerah yang ada di Kawasan Timur Indonesia. Untuk wilayah Kawasan Timur Indonesia, Makassar-lah yang paling banyak memiliki perguruan tinggi, baik negeri maupun swasta. Tercatat 60 perguruan tinggi yang ada di Makassar yang terdiri atas 3 universitas negeri, 14 universitas swasta, 3 sekolah tinggi negeri, 27 sekolah tinggi swasta, dan 13 akademi. Adapun jumlah mahasiswa di Makassar berkisar pada angka 161.437 mahasiswa. Mahasiswa tersebut berasal dari berbagai daerah di Kawasan Timur Indonesia, bahkan sebagian juga ada yang berasal dari Jawa dan Sumatera.

Sikap hidup mahasiswa di kota ini (selain kesibukan akademik) pada umumnya berada pada tiga posisi. Yaitu, sikap hidup modern dengan gaya hidup konsumtifyang sangat dipengaruhi oleh tampilan media, sikap hidup religius yang sangat didominasi oleh komitmen keagamaan, serta sikap hidup mahasiswa yang terjun dalam dunia aktivis kemahasiswaan. Meskipun demikian, tidak sedikit juga mahasiswa yang hanya menghabiskan "usia" akademiknya dengan hanya berfokus pada kegiatan akademik semata. Mahasiswa yang memiliki pola hidup modern, umumnya menghabiskan waktunya pada tempat-tempat yang mencirikan gaya hidup modern, seperti mall, kafe, bioskop, dan lain-lain. Sedangkan mahasiswa yang lebih berorientasi pada religuisitas banyak menghabiskan waktunya di tempat ibadah atau di organisasi keagamaanny. Untuk mahasiswa yang terjun pada dunia aktivis

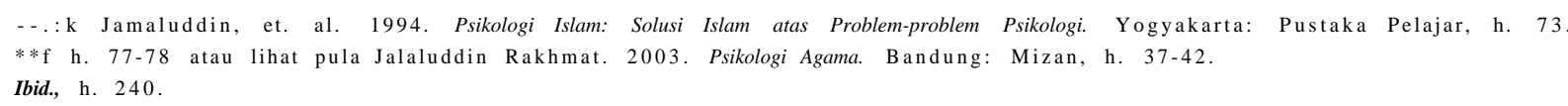


kampus banyak menghabiskan waktunya pada kegiatan-kegiatan organisasi kemahasiswaan baik intra maupun ekstra kampus, menghabiskan banyak waktunya pada kegiatan-kegiatan keorganisasian maupun demonstrasi. Ketiganya menampilkan sikap dan gaya hidup yang berbeda satu dengan lainnya.

Mengenai paham dan sikap keagamaan mahasiswa Islam secara umum di Makassar, ketiga pola hidup kemahasiswaan tersebut sangat mempengaruhi paham dan sikap serta-penerimaan mereka terhadap paham dari kelompok keagamaan yang datang "menyapa" mereka. Maraknya berbagai kelompok keagamaan dengan berbagai paham keislaman di kampus-kampus menunjukkan adanya sikap apresiatif mahasiswa muslim Makassar terhadap hal tersebut. Kajian-kajian keislaman yang bernuansa ideologis maupun intelektual cukup marak, baik yang dilakukan oleh organisasi kemahasiswaan seperti HMI, PMII, IMM, KAMMI sertayang dilakukan oleh kelompok keislaman yang berlatar belakang ideologi transnasional seperti Hizbut Tahrir, Ikhwanul Muslimin, Salary, dan Syiah. Hadirnya paham Syiah melalui buku-buku yang ditulis oleh tokoh-tokoh Syiah baik dari luar negeri, khususnya Iran maupun dari dalam negeri membawa konsep ideologis agama sebagai konsep pergerakan yang banyak diilhami oleh Revolusi Islam Iran, memberikan inspirasi sekaligus aspirasi, "mempermak" simbolisme keagamaan dalam bingkai rasionalitas yang argumentatif cukup menarik minat mahasiswa muslim baik yang memiliki kecenderungan pada sikap religius maupun mereka yang berkecimpung pada dunia aktivis kemahasiswaan

\section{Syiah dalam Pandangan Mahasiswa Islam di Makassar}

Berdasarkan wawancara peneliti terhadap mahasiswa dari berbagai kalangan, umumnya mereka telah mengenai adanya kelompok Syiah dalam Islam. Berdasarkan hasil wawancara, peneliti menemukan ada empat kategori para mahasiswa muslim di Makassar mengenai Syiah. Pertama. Mereka mengenai Syiah melalui buku-buku tentang Syiah yang banyak beredar di Makassar. Kedua. Mereka mengenai Syiah setelah melihat maraknya kegiatankegiatan seremonial/ritual Syiah yang kerap dilakukan secara terbuka seperti peringatan hari asyura, arbain, al-ghadir, dan lain-lain, bahkan sering dilakukan di kampus. Ketiga. Mengenai Syiah setelah mengikuti kajian atau pernah mengikuti proses kaderisasi yang dilakukan oleh lembaga-lembaga Syiah yang ada di Makassar, Keempat. Mereka mengenai Syiah melalui interaksi dengan teman-teman kampus atau kost mereka yang menganut paham Syiah.

Setelah mengenai Syiah, pandangan mereka cukup beragam, bagi yang mengenai dan kemudian mengikuti paham Syiah, mereka memandang bahwa Syiah merupakan kelompok Islam yang mampu memberikan penjelasan-penjelasan rasional atas doktrin-doktrin Islam melalui pendekatan logika dan filsafat. Hal ini seperti diungkapkan oleh Muh Takbir (UIN), Bahrul Amsal (UNM), Amran Amin (Unismuh), Nurhidayah (Unhas), Fathir (UMI), Buya Rumadau (STIEM), dan Habibi (STIMIIK Dipanegara). Selain wacana keislaman yang sarat dengan pendekatan filsafat yang sangat diminati oleh sebagian kalangan mahasiswa. Syiah juga dianggap sebagai gerakan keagamaan revolusioner yang dapat membalik tesis Karl Marx,'seperti yang diungkapkan oleh Faisal Pusadan (UIT) dan Zulkarnaen (UNM) yang merupakan eks aktivis LMND (organisasi kemahasiswaan yang berhaluan kiri) melihat Syiah apalagi dengan gerakan revolusi Islam Iran sebagai pilihan gerakan yang dapat menjadi wadah untuk menyalurkan semangat revolusioner mereka. Pencitraan Syiah sebagai gerakan keagamaan yang sarat dengan semangat revolusioner inilah yang membuat banyak aktivis mahasiswa menjadi tertarik untuk mengenai Syiah lebih jauh dan tak sedikit yang akhirnya menjadi penganut Syiah.

Pandangan bahwa Syiah sebagai mazhab Islam yang sarat dengan pendekatan rasional dalam menjelaskan doktrin-doktrin keislaman serta sarat dengan semangat ideologi yang revolusioner tidak hanya diungkapkan oleh mereka yang kemudian secara sadar menjadikan Syiah sebagai paham keagamaannya. Mereka yang tetap pada paham keagamaan sebelumnya (Sunni) namun mengenai Syiah melalui buku-buku maupun kajian pun berpandangan seperti itu. Muh Akmal (UIN) yang sering mengikuti kajiankajian yang diadakan oleh kelompok Syiah namun mengaku tetap bermazhab Sunni pun mengatakan bahwa "harus diakui kelompok Syiah cukup rasional 
JUani menjelaskan doktrin keislaman, sejarah revolusi sarn Iran tahun 1979 juga membuat Syiah dikenal

za gerakan keagamaan yang revolusioner,

•-mgkin karena mereka menjadikan kajian logika, dan Tauhid yang bernuansa pembebasan ajian wajib. Dan harus diakui hal ini hampir

Mbk ditemui di Sunni." Ketika ditanya kenapa tak ti paham Syiah? Akmal menjawab; "Apresiatif Syiah tidak mesti mengikuti Syiah secara

Pernyataan yang hampir senada juga -^an oleh beberapa mahasiswa yang penulis

selain pandangan tersebut di atas tak sedikitjuga - vva muslim di Makassar yang berpandangan :erhadap Syiah. Stigma bahwa Syiah adalah

ib yang sesat dan menyimpang dari ajaran Is-

: akini oleh kalangan mahasiswa, khususnya *aag aktif pada kelompok-kelompok yang berhauan

if: Beberapa mahsiswa Salafi yang peneliti temui ir.ya berpandangan bahwa Syiah adalah *; :rnppok sesat dalam Islam, bahkan sebagian Jfafiranya berpandangan bahwa Syiah telah keluar Jari Islam. Bagi mahasiswa yang aktif di kelompok Kzbut Tahrir, KAMMI, dan IMM yang dikenal «bagai organisasi kemahasiswaan yang puritan -t-randangan cukup bervariasi, ada yang sepakat, flengan pandangan bahwa Syiah adalah kelompok tienyimpang dari Islam, namun sebagian juga iangan bahwa Syiah adalah mazhab dalam Jsiam yang meski berbeda dengan Sunni namun -e-eka tetap bagian dari Islam. Sedangkan - i - asiswa muslim yang berpandangan moderat yang reneliti temui berpandangan bahwa Syiah adalah o isanah dalam Islam yang tetap harus diakui sebagai $<<$ rmpokdalam Islam.

Proses Kaderisasi Syiah dan Penanaman F crilaku Sosial Keagamaan pada Mahasiswa Isjm di Kota Makassar

Proses kaderisasi dan penyebaran paham Syiah : kota Makassar dilakukan melalui beberapa lembaga, raik ormas, yayasan-yayasan Syiah, serta kelompok-

mpok studi yang intensif melakukan pengkajian ;- .adap wacana dan pemikiran Syiah. Sebagaimana : -etahui, di Indonesia telah ada satu ormas yang berafdiasi pada pemikiran mazhab Syiah, yaitu IJABI (Ikatan Jamaah Ahlulbayt Indonesia) yang didirikan di Bandung pada tanggal 1 Jul, 2000. Di Makassar, sejak tahun 2000 telah berdiri kepengurusan daerah IJABI dan kini telah memiliki 9 pengurus cabang di tingkat kecamatan dari 14 kecamatan yang ada di kota Makassar. ${ }^{10}$ Meskipun dalam misi IJABI yaitu untuk menghimpun pencinta Ahlulbayt dari mazhab manapun, tapi tak bisa dipungkiri bahwa pendirian dan pengembangan IJABI dipelopori oleh tokoh-tokoh pencinta Ahlulbayt dari kalangan Syiah Imamiyah." Dengan demikian, IJABI sebagai ormas cukup didominasi oleh pola-pola pemikiran yang berorientasi pada mazhab Syiah Imamiyah.

Kota Makassar merupakan salah satu kota yang menjadi basis IJABI selain pusatnya di Bandung. Selama satu dasawarsa sejak berdirinya, IJABI di Makassar telah berhasil melakukan kaderisasi, khususnya di kalangan mahasiswa muslim sehingga banyak merekrut kader-kader dari kalangan mahasiswa. Dalam memperkenalkan paham Ahlulbayt (baca: Syiah), IJABI menggunakan beberapa metode. Selain proses kaderisasi formal organisasi, IJABI juga intensif melakukan kajian-kajian logika, filsafat dan tema-tema keislaman yang bercorak Syiah. Selain itu, peringatan hari-hari besar Islam dalam mazhab Syiah, seperti asyura, arha 'in, idul ghadir, serta peringatan syahadah dan wiladah para Imam-imam Syiah dan Fatimah az-Zahra menjadi momentum yang mereka gunakan untuk mensosialisasikan dan menanamkan paham dan prilaku keagamaan yang bercorak Syiah kepada kader-kadernya yang umumnya adalah mahasiswa. Seperti yang dituturkan oleh salah seorang fungsionaris IJABI Sulsel, proses penanaman paham dan prilaku keagamaan dilakukan dengan pendekatan intelektual melalui kajian dan diskusi,juga melalui pendekatan spiritual dengan ritual-ritual dan doadoa pada momen-momen tertentu atau pada malammalam tertentu seperti malam Rabu dan malam Jumat. Kegiatan-kegiatan sosial juga kerap dilakukan guna memperkenalkan IJABI kepada masyarakat serta guna mewujudkan misi IJABI yang kedua, yaitu untuk melakukan pembelaan kepada kaum mustadh 'afin.

Sembilan kecamatan yang telah berdiri pengurus cabang IJABI tersebut adalah: Kecamatan Tamalate, Marisso, Rappocini. Manggala, irikukang, Tallo, Tamalanrea, Bontoala, dan Biringkanaya

Musriadi. 2009. Perm Ikatan Jamaah Ahlulbayt Indonesia (IJABI) dalam Perubahan Sosial Keagamaan Mahasiswa Islam di -.-ersitas Negeri Makassar (UNM). Makassar: PPs. UNM, h. 105 
Selain IJABI, proses kaderisasi dan penyebaran paham Syiah di Makassar juga didukung oleh beberapa yayasan dan kelompok studi. Berdasarkan temuan peneliti ada 9 yayasan Syiah di Makassar ${ }^{12}$ yang aktifmelakukan proses kaderisasi paham Syiah kepada masyarakat. Kesemua yayasan tersebut berdasarkan temuan peneliti merekrut kader umumnya dari kalangan mahasiswa. Pendekatan yang mereka pakai pun adalah pendekatan yang cukup menarik minat mahasiswa untuk mengikuti yaitu dengan pendekatan intelektual melalui kajian logika, filsafatjjV/crn (tasawuf), wacana sosial, dan wacana keislaman yang bercorak Syiah. Proses penanaman paham dan perilaku keagamaan yang bercorak Syiah juga dilakukan dengan intensif mengadakan ritual dan doa-doa yang rutin dilakukan. Selain IJABI dan yayasan proses kaderisasi dan penanaman paham dan prilaku keagamaan yang bercorak Syiah juga didukung oleh maraknya kelompok-kelompok studi mahasiswa yang intensif melakukan kajian dan diskusi seputar wacana-wacana Syiah. Kelompok-kelompok studi tersebut umumnya berlokasi di sekitar wilayah kampus, sehingga dengan mudah merekrut kader-kader dari kalangan mahasiswa. ${ }^{13}$

Pengiriman mahasiswa-mahasiswa dari Makassar untuk menempuh studi di Iran, baik di hauzah-hauzah ilmiyah yang khusus mempelajari ilmu-ilmu keislaman versi Syiah di Qum maupun di Teheran (Iran). Saat ini, setidaknya ada puluhan mahasiswa Makassar yang saat ini menempuh studi baik SI, S2, dan S3 di Iran. ${ }^{14}$ Pada waktu-waktu tertentu, khususnya di bulan Ramadhar. mereka dipulangkan ke Makassar untuk berlibur dan sekaligus melakukan dakwah Syiah. Sehingga ketika bulan Ramadhan marak sekali kegiatan-kegiatan yang diisi oleh pelajar-pelajar dari Iran tersebut. Komunitas Syiah di Makassar juga berulang kali mendatangkan ulama-ulama Syiah baik dari Iran, Irak, Inggris, dan negara-negara lain. Hal ini dilakukan dalam rangka membangun kerjasama antar komunitas Syiah yang ada di Makassar dengan komunitas Syiah yang ada di luar negeri. Selain itu, kedatangan mereka juga dimanfaatkan untuk memberikan pencerahan kepadajamaah Syiah di Makassar tentang ajaran Syiah baik dari segi pahaman maupun prilaku keagamaan.

Pada wilayah paham keagamaan, setidaknya ada dua doktrin dasar mengena'i paham keagamaan yang ditanamkan, yaitu: secara aqliah, keyakinan keagamaan harus sesuai dan sejalan dengan akal sehat dan nilai-nilai rasionalitas dan secara naqliah keyakinan keagamaan haruslah mempunyai landasan yang kuat berdasarkan Alquran dan hadis. ${ }^{15}$ Dengan demikian paham keagamaan yang ditanamkan adalah sinergitas antar'a akal dan naql. Pada sikap keagamaan yang ditanamkan adalah aplikasi keagamaan baik pada ranah individu maupun sosial. Penanaman sikap keagamaan yang cukup menarik minat mahasiswa adalah doktrin tentang prilaku keagamaan yang harus berkorelasi dengan sikap kritis atas fenomena sosial. ${ }^{16}$ Penanaman sikap keagamaan ini merupakan proses transformasi semangat revolusi Islam Iran yang diserukan oleh Imam Khomeini pada tahun 1979.

\section{Perubahan Paham dan Perilaku Keagamaan} Mahasiswa Islam yang Menjadi Penganut Syiah

Dengan menggunakan pendekatan intelektual serta transformasi semangat rovlusi Islam Iran, proses penanaman paham dan prilaku keagamaan yang dilakukan oleh para aktivis Syiah di Makassar cukup banyak menarik minat para mahasiswa, khususnya dari kalangan aktivis untuk bergabung. Pendekatan ini tentu saja memberikan dampak berupa perubahan paham dan perilaku keagamaan para mahasiswa dari sebelum dan sesudah menjadi Syiah.

Berdasarkan hasil wawancara peneliti dengan beberapa informan, ditemukan beberapa perubahan paham dan prilaku keagamaan dari mereka dari sebelum dan sesudah menjadi penganut Syiah. Sebelum mengenal dan menjadi Syiah, mereka

"Yayasan-yayasan tersebut adalah Yayasan al-Islah, Lentera, LSIf, LDSI al-Muntazhar, Yayasan Shadra, Yayasan Mafatihul Jinan, Yayasan ash-Shodiq, Yayasan Rausyan Fikr dan Yayasan el-Hurr.

Berdasarkan temuan peneliti di hampir setiap kampus yang ada di Makassar bermunculan kelompok-kelompok studi yang intensif melakukan kajian dan diskusi seputar wacana Syiah kelompok-kelompok studi ini juga aktif melakukan kaderisasi melalui perekrutan anggota. Masing-masing kelompok studi umumna beranggotakan dari 20 sampai 100-an anggota

"Umumna mereka yang menempuh studi di Iran tidak berlatarbelakang pendidikan agama sebelumna. Kebanyakan dari mereka sebelumnya menempuh studi di Unhas, UNM, UMI, dan bukan dari perguruan Agama seperti UIN/IAIN atau pesantren.

'Musriadi, op. cit., h. 112 .

"Ibid., h. 114 . 
wagakui bahwa mereka belum me^idapatkan atas doktrin-doktrin keislaman yang tak :- i kehausan intelektual. Sebelum mengenal tm menjadi Syiah, mereka merasakan ajaran - ar yang mereka dapatkan lebih cenderung at hitam-putih dan doktriner. Setelah mengikuti - -a an Syiah mereka mulai mendapati sebuah i-.ahi keislaman yang bersifat terbuka dan ; : < ual. Hal ini sangat dimaklumi karena kajiani." $S \backslash$ ah yang umumnya dilakukan menggunakan - - tan logika dan filsafat dalam menjelaskan

< keislaman. Wacana pluralismeyangdiusung 31 sebagai brandgerakan mereka pun cukup rengaruhi pemikiran kader-kader mereka,

-a di kalangan mahasiswa yang akhirnya : . a: paham keagamaan mereka menjadi

\section{"crtxika}

Dari segi sikap keagamaan, perubahan yang rr.enyangkut aspek personal dan sikap sosial. _: aran intelektual yang menjadi basis paham

. - - a a n mereka berimplikasi pada penyikapan Ms ritual-ritual keagamaan yang mereka lakukan. tidak dipandang lagi sebagai kevvajiban yang aksa melainkan konsekuensi logis dari paham * iigamaan. Sehingga pelaksanaan ritual keislaman _di intensif mereka lakukan. Dan tentu saja adi perubahan model pelaksanaan ritual yang lasarkan padafiqh Syiah yang menganut fiqh ab Ja'fari, sehingga pelaksanaan ritual ibadah ing dilakukan sangat berbeda dengan ritual ibadah ;-ing dilakukan oleh umat Islam pada umumnya. $\mathrm{r}^{\wedge} \mathrm{eda}$ an tata cara ibadah ini tentu saja menuai prob: . ketika dihadapkan dengan tata cara ibadah umat - am pada umumnya, hal ini berimplikasi pada sikap arg meski taat melaksanakan shalattapi malas untuk inunaikannya di Mesjid, sehingga interaksi dengan -at Islam yang lain di Mesjid menjadi sangat kurang.

${ }^{\mathrm{N}}$ ikap jarang ke Mesjid ini semakin diperkuat dengan i aran fiqh mereka yang tidak mewajibkan shalat -mat secara mutlak selama keghaiban Imam Mahdi, sehingga walaupun pada saat pelaksanaan shalat .'-mat, umat Islam berbondong-bondong ke Mesjid -ntuk menunaikan shalat Jumat, mereka umumnya enggan melaksanakannya.

Pada prilaku sosial keagamaan, dengan doktrin - cagamaan untuk selalu bersikap kritis terhadap omena sosial yang terjadi, membuat umumnya mahasiswa yang menganut paham Syiah semakin reaksioner terhadap kondisi sosial dan hal ini didasarkan pada doktrin keagamaan dan dianggap sebagai perwujudan sikap keagamaan. ${ }^{17}$ Dalam hal interaksi sosial, paham pluralisme yang diusung membuat sikap sosial mereka cenderung lebih terbuka untuk berinteraksi dengan orang dari berbagai latar belakang keyakinan serta tidak menunjukkan sikap-sikap eksklusif dalam pergaulan.

\section{PENUTUP}

\section{Kesimpulan}

Mahasiswa muslim yang ada di Kota Makassar umumnya mengenal Syiah melalui kajian-kajian, bukubuku bacaan yang bertemakan Syiah, acara-acara seremonial yang diadakan oleh kalangan Syiah, dan melalui interaksi dengan kawan atau kerabat yang menganut Syiah. Tanggapan pun beragam, ada yang merespon secara positif dan kemudian memutuskan menjadi penganut Syiah, merespon positifmeski tidak melakukan perpindahan mazhab, dan bersikap negatif dengan berpandangan stigmatik atas Syiah secara umum sebagai aliran sesat dan menyimpang dari ajaran Islam.

Proses kaderisasi dan penanaman paham dan prilaku keagamaan yang bercorak Syiah' di kota Makassar dilakukan oleh ormas IJABI, 9 yayasan, dan beberapa kelompok studi yang umumnya membidik sektor kampus dan menjadikan mahasiswa sebagai sasaran. Proses penanaman paham dan prilaku keagamaan dilakukan dengan pendekatan intelektual melalui kajian dan diskusi, pendekatan spiritual dengan mengadakan acara ritual doa-doa pada momen dan malam-malam tertentu, pendekatan ideologis dengan melakukan transmisi semangat revolusi Islam Iran 1979.

Perubahan paham dan prilaku keagamaan dari kalangan mahasiswa muslim yang menjadi penganut Syiah terlihat pada pemahaman keagamaan yang bersifat rasional dalam memahami dan menjelaskan pokok-pokok keyakinan agama. Dari segi prilaku keagamaan tampak pada perubahan tata cara ibadah yang mengikuti pola fiqh Syiah yang menganut fiqh Ja'fari. Hal ini berimplikasi pada interaksi dengan umat Islam yang lain, terkhusus pada ritual keagamaan.

"Umumna para mahasiswa yang menjadi penganut Syiah adalah aktivis mahasiswa yang aktif di organisasi kemahasiswaan baik intra -iupun ekstra kampus, sehingga mereka memiliki wadah untuk menyalurkan sikap kritis-reaksioner tersebut. 
Mereka menjadi jarang ke mesjid diakibatkan perbedaan dalam tata ritual ibadah yang dilakukan dengan umat Islam secara umum. Pada prilaku sosial keagamaan, mereka yang sangat terpengaruh oleh semangat revolusi Islam Iran membuat munculnya sikap revolusioner dalam menyikapi fenomena sosial dan hal tersebut mereka sandarkan pada ajaran agama.

\section{Rekomendasi}

a. Kepada para penganut Syiah, khususnya dari kalangan mahasiswa muslim di Makassar, hendaknya senantiasa bersikap terbuka dan interaktif terhadap umat Islam yang lain. Sedapat mungkin meretas jurang perbedaan dan lebih bersikap akomodatif terhadap kecenderungan paham dan sikap keagamaan umat islam mainstreem di Makassar, guna menghindari terjadinya gesekan konflik horisontal antar mazhab.

b. Kepada pihak Kementerian Agama, hendaknya bersikap akomodatif dan tetap melakukan pembinaan terhadap berbagai varian keagamaan yang berkembang di masyarakat. Serta bersikap proaktif dalam upaya pencegahan potensi konflik akibat perbedaan paham keagamaan.

\section{Ucapan Terimakasih}

Ucapan terima kasih tak terhingga peneliti ucapkan kepada rekan-rekan mahasiswa yang menjadi informan kami dalam penelitian ini. Demikian pula pada rekan-rekan pengurus IJABI dan yayasanyayasan Syiah di Makassar atas kesediaannya memberikan informasi guna melengkapi data-data penelitian ini. Terima kasih tak terhingga dihaturkan pula pada pihak redaksi jurnal al-Qalam atas kesediaannya memuat tulisan hasil penelitian ini.

\section{DAFTAR PUSTAKA}

Azra, Azyumardi. 1995. "Syiah di Indonesia; Antara Mitos dan Realitas". Jurnal Ulumul Qur'an No. 4,Vol.VI, Tahun 1995.

Jamaluddin, Aricok. et. al. 1994. Psikologi Islam: Solusi Islam atas Problem-problem Psikologi, Yogyakarta: Pustaka Pelajar.

Musriadi. 2009. Peran Ikatan Jamaah Ahlulbayt Indonesia (IJABI) dalam Perubahan Sosial Keagamaan Mahasiswa Islam di Universitas Negeri Makassar (UNM). Makassar: PPs UNM.
Rakhmat, Jalaluddin. 2003. Psikologi Agama. Bandung: Mizan. Safwan, AM. 2010. IJABI Sebagai Gerakan Sosial Keagamaan, dalam http://ressay.wordpress.com/2007/01/05/ikatanjamaah-Ahlulbayt-indonesia-ijabi-sebagai-gerakan-sosialkeagamaan/ diakses tanggal 22 Otober 2010.

Syirazi. 2002. Nasir Makarim. Inilah Aqidah Syiah. Jakarta: alHuda.

Tijani, Muhammad. 2007. al-Syiah hum AhlSunnah, Diterjemahkan dengan Judul Syiah Sebenar-benarnya Ahlussunnah: Study Kritis-Informatif antara Klaim danFakta, Jakarta: el-Faraj. 